\author{
О. І. Панасенко ${ }^{1}$, Л. М. Горяча 2 , В. В. Гуцол ${ }^{3}$ \\ ЗАПОРІЗЬКИЙ ДЕРЖАВНИЙ МЕДИЧНИЙ УНІВЕРСИТЕТ \\ НАЦІОНАЛЬНИЙ ФАРМАЦЕВТИЧНИЙ УНІВЕРСИТЕТ ${ }^{2}$, ХАРКІВ \\ ВІННИЦЬКИЙ НАЦІОНАЛЬНИЙ МЕДИЧНИЙ УНІВЕРСИТЕТ ІМЕНІ М. І. ПИРОГОВА
}

\title{
ДОСЛІДЖЕННЯ ОРГАНІЧНИХ КИСЛОТ У СИРОВИНІ АМБРОЗІї ПОЛИНОЛИСТОї
}

Вступ. Перспективною групою біологічно активних речовин рослинного походження є органічні кислоти. Органічні кислоти проявляють протизапальну, антиоксидантну, гепатозахисну, протимікробну активність, також вони беруть участь в обміні речовин та покращують стан мікрофллори кишечника. У літературі досить обмежені дані щодо органічних кислот амброзії полинолистої, тому дослідження цієі групи біологічно активних речовин у сировині амброзії було актуальним.

Мета дослідження - вивчити органічні кислоти в сировині амброзії полинолистої у різні фрази розвитку рослини.

Методи дослідження. Дослідження органічних кислот проводили методом газової хроматограсрії в листі й коренях амброзії полинолистої, заготовлених у фразу вегетації, на початку бутонізації та у фразу плодоношення.

Результати й обговорення. У листі амброзії полинолистої, заготовленому у фазу вегетації, в найбільшій кількості було визначено лимонну (4769,3 мг/кг) та оксалатну (2046,8 мг/к2) кислоти, в коренях цієї фрази - фрумарову (2580,9 мг/кг) і лимонну (782,3 мг/кг). У листі, заготовленому на початку бутонізації, за вмістом превалювали оксалатна (1374,4 мг/к2) і лимонна (813,0 мг/к2) кислоти, в коренях цієї фрази лимонна (1705,1 мг/кг) та яблучна (1399,5 мг/к2). У листі, заготовленому у фазу плодоношення, домінували лимонна (2879,4 мг/кг) та оксалатна (513,5 мг/кг) кислоти, у коренях цієї фрази за вмістом переважали фрумарова (242,2 мг/ке) та яблучна (186,7 мг/кг) органічні кислоти.

Висновки. Методом газової хроматографрії було досліджено органічні кислоти в листі й коренях амброзії полинолистої, заготовлених у фразу вегетації, на початку бутонізації та у фразу плодоношення. У досліджуваній сировині за вмістом домінували аліфратичні карбонові кислоти, зокрема лимонна, оксалатна, малонова, фуммарова та яблучна. Найбільший вміст органічних кислот було визначено в листі, заготовленому у фразу вегетації. Одержані результати дають змогу спрогнозувати антиоксидантну та протимікробну активність лікарських рослинних засобів на основі сировини амброзії полинолистої.

КЛЮчОВІ СЛОВА: амброзія полинолиста; органічні кислоти; газова хроматографія.

ВСТУП. Пошук нових рослинних джерел біологічно активних речовин є актуальним напрямком роботи сучасної фрармацевтичної галузі України. Для розширення асортименту лікарських рослин необхідно поглибити знання щодо їх хімічного складу.

Перспективною групою біологічно активних речовин рослинного походження $€$ органічні кислоти. Відомо, що їх широко застосовують у фрармацевтичній, косметичній, харчовій промисловості [1-3]. Органічні кислоти проявляють протизапальну, антиоксидантну, гепатозахисну, протимікробну активність, також вони беруть участь в обміні речовин та позитивно впливають на мікрофрлору кишечника [4-6].

(c) О. І. Панасенко, Л. М. Горяча, В. В. Гуцол, 2018.
До перспективних рослин належить амброзія полинолиста (Ambrosia artemisiifolia L.) родини айстрових (Asteraceae), яку здавну використовують у народній медицині. Настоями, настойками та екстрактами 3 трави, листя, коренів і квіток рослини лікують інфекційні та запальні захворювання, а також розлади серцево-судинної системи, шлунково-кишкового тракту [7].

У літературі досить обмежені дані щодо органічних кислот амброзії полинолистої, тому дослідження цієї групи біологічно активних речовин у сировині амброзії було актуальним.

Мета дослідження - вивчити органічні кислоти в сировині амброзії полинолистої у різні фрази розвитку рослини. 
МЕТОДИ ДОСЛІДЖЕННЯ. Об'єктами дослідження було обрано листя і корені амброзії полинолистої, заготовлені у фразу вегетації, на початку бутонізації та у фазу плодоношення.

Ідентифрікацію органічних кислот та визначення їх кількісного вмісту в досліджуваних об'єктах проводили методом газової хроматографрії за такою методикою.

50 мг сировини вміщували у віалу на 2 мл, додавали внутрішній стандарт (50 мкг тридекану в гексані) та приливали 1 мл метилюючого агента (14 \% ВСl в метанолі, Supelco 3-3033). Суміш витримували в герметично закритій віалі 8 год при $65^{\circ} \mathrm{C}$. Реакційну суміш фрільтрували і додавали 1 мл води очищеної. Для вилучення метилових естерів карбонових кислот додавали 0,2 мл хлористого метилену, акуратно струшували декілька разів протягом години, а потім проводили хроматограсрування.

Пробу (2 мкл) вводили в хроматографрічну колонку в режимі splitless, тобто без поділу потоку, що дозволило ввести пробу без втрат на поділ та значно (в 10-20 разів) збільшити чутливість методу хроматографрування. Швидкість введення проби - 1,2 мл/хв протягом 0,2 хв.

Аналіз проводили за таких умов хроматографрування: хроматографрічна колонка - капілярна INNOWAX, внутрішній діаметр - 0,25 мм, довжина - 30 м; швидкість газу-носія (гелій) 1,2 мл/хв; температура випаровувача $-250{ }^{\circ} \mathrm{C}$ температуру термостата запрограмовано від 50 до $250^{\circ} \mathrm{C}$ зі швидкістю 4 град/хв.

Для ідентисрікації компонентів використовували бібліотеку мас-спектрів NIST 05 та WILEY 2007 із загальною кількістю спектрів понад 470000 у поєднанні з програмами для ідентифрікації AMDIS і NIST [8].

Для розрахунку кількісного вмісту застосовували метод внутрішнього стандарту. Розраху-

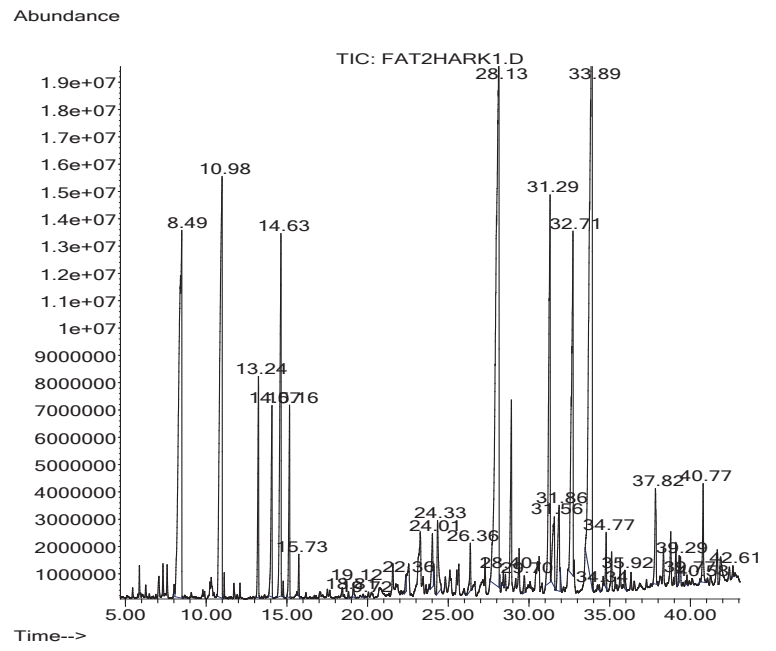

Рис. 1. Хроматограма органічних кислот листя амброзії полинолистої, заготовленого на початку бутонізації. нок вмісту компонентів ( $C$, мг/кг) проводили за фрормулою:

$$
C=K_{1} \cdot K_{2} \cdot 1000
$$

де $K_{1}=\Pi_{1} / \Pi_{2}\left(\Pi_{1}-\right.$ площа піку речовини, що досліджується, $\Pi_{2}$ - площа піку стандарту);

$K_{2}=50 / \mathrm{M}(50-$ маса внутрішнього стандарту (мкг), який вводили у зразок, М - наважка зразка (Мг)).

РЕЗУЛЬТАТИ Й ОБГОВОРЕННЯ. ОДерЖані хроматограми наведено на рисунках 1 i 2.

Час утримання та кількісний вміст домінуючих органічних кислот сировини амброзії полинолистої представлено в таблицях 1 і 2.

У листі амброзії полинолистої у фразу вегетації в найбільшій кількості було визначено лимонну (4769,3 мг/кг), оксалатну (2046,8 мг/кг) та малонову $(1044,7$ мг/кг) кислоти, в дещо меншій - яблучну (528,8 мг/кг) кислоту. Такожу листі цієї фрази в значній кількості містились фрумарова, фрерулова та бурштинова кислоти.

Корені амброзії полинолистої у фазу вегетації накопичували у великій кількості фумарову (2580,9 мг/кг), лимонну (782,3 мг/кг), яблучну (579,5 мг/кг) та оксалатну (521,7 мг/кг) кислоти.

У листі, заготовленому на початку бутонізації, за вмістом превалювали оксалатна (1374,4 мг/кг) та лимонна (813,0 мг/кг) кислоти. У коренях амброзії полинолистої, які було заготовлено на початку бутонізації, в найбільшій кількості містилися лимонна (1705,1 мг/кг), яблучна (1399,5 мг/кг), срумарова (1232,2 мг/кг), оксалатна (1105,9 мг/кг) кислоти.

У листі у фазу плодоношення за вмістом домінували лимонна $(2879,4$ мг/кг), оксалатна (513,5 мг/кг), малонова (448,6 мг/кг), яблучна (290,0 мг/кг), бурштинова (257,6 мг/кг) та фрумарова $(240,8$ мг/кг) кислоти. У коренях цієї фрази за вмістом переважали фрумарова (242,2 мг/кг),

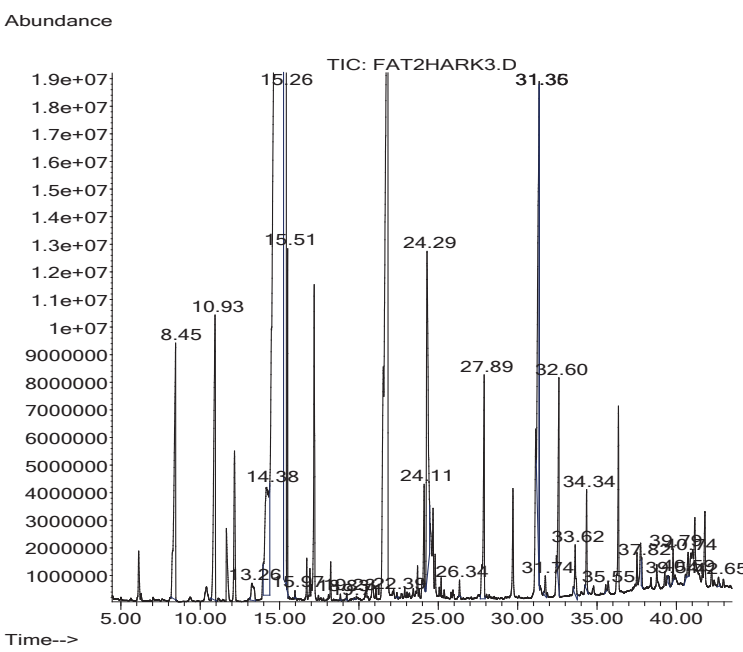

Рис. 2. Хроматограма органічних кислот коренів амброзії полинолистої, заготовлених на початку бутонізації. 
Таблиця 1 - Час утримання домінуючих органічних кислот у сировині амброзії полинолистої

\begin{tabular}{|c|c|c|c|c|c|c|}
\hline \multirow{3}{*}{$\begin{array}{c}\text { Домінуючі } \\
\text { кислоти }\end{array}$} & \multicolumn{6}{|c|}{ Час утримання, хв } \\
\hline & \multicolumn{2}{|c|}{ фраза вегетації } & \multicolumn{2}{|c|}{ початок бутонізації } & \multicolumn{2}{|c|}{ фраза плодоношення } \\
\hline & листя & корені & листя & корені & листя & корені \\
\hline \multicolumn{7}{|c|}{ Аліфатичні кислоти } \\
\hline Оксалатна & 10,00 & 9,98 & 10,98 & 10,93 & 9,87 & 9,85 \\
\hline Малонова & 12,35 & 12,35 & 13,24 & 13,26 & 12,19 & 12,18 \\
\hline Фумарова & 13,12 & 13,28 & 14,07 & 14,38 & 12,93 & 12,93 \\
\hline Бурштинова & 14,24 & 14,29 & 15,16 & 15,51 & 14,03 & 14,05 \\
\hline Яблучна & 23,16 & 23,07 & 24,33 & 24,29 & 23,39 & 22,83 \\
\hline Лимонна & 30,31 & 30,27 & 31,29 & 31,36 & 29,91 & 29,78 \\
\hline \multicolumn{7}{|c|}{ Ароматичні кислоти } \\
\hline Бензойна & 14,79 & 14,81 & 15,73 & 15,97 & 14,53 & 14,55 \\
\hline Бузкова & - & 38,78 & 39,77 & 39,80 & 38,33 & 38,27 \\
\hline Ферулова & 41,34 & 41,31 & 42,61 & 42,65 & 40,85 & 40,74 \\
\hline
\end{tabular}

Таблиця 2 - Вміст домінуючих органічних кислот у сировині амброзії полинолистої

\begin{tabular}{|c|c|c|c|c|c|c|}
\hline \multirow{3}{*}{ Назва кислоти } & \multicolumn{6}{|c|}{ Вміст кислоти, мг/кг } \\
\hline & \multicolumn{2}{|c|}{ фраза вегетації } & \multicolumn{2}{|c|}{ початок бутонізації } & \multicolumn{2}{|c|}{ фраза плодоношення } \\
\hline & листя & корені & листя & корені & листя & корені \\
\hline \multicolumn{7}{|c|}{ Аліфатичні кислоти } \\
\hline Оксалатна & 2046,8 & 521,7 & 1374,4 & 1105,9 & 513,5 & 97,6 \\
\hline Малонова & 1044,7 & 129,2 & 270,5 & 131,4 & 448,6 & 74,1 \\
\hline Фумарова & 422,6 & 2580,9 & 283,0 & 1232,2 & 240,8 & 242,2 \\
\hline Бурштинова & 281,8 & 251,8 & 240,2 & 323,0 & 257,6 & 66,1 \\
\hline Яблучна & 528,8 & 579,5 & 148,3 & 1399,5 & 290,0 & 186,7 \\
\hline Лимонна & 4769,3 & 782,3 & 813,0 & 1705,1 & 2879,4 & 142,7 \\
\hline \multicolumn{7}{|c|}{ Ароматичні кислоти } \\
\hline Бензойна & 195,1 & 18,1 & 38,6 & 10,9 & 53,4 & 7,4 \\
\hline Бузкова & - & 38,9 & 9,7 & 56,8 & 39,5 & 88,4 \\
\hline Ферулова & 455,4 & 117,0 & 11,9 & 25,9 & 19,4 & 15,8 \\
\hline
\end{tabular}

яблучна (186,7 мг/кг), лимонна (142,7 мг/кг) та ванілінова (123,0 мг/кг) карбонові кислоти.

ВИСНОВКИ. 1. Методом газової хроматографії було досліджено органічні кислоти в листі й коренях амброзії полинолистої, заготовлених у фразу вегетації, на початку бутонізації та у фразу плодоношення.

2. У досліджуваній сировині за вмістом домінували аліфатичні карбонові кислоти, зокрема лимонна, оксалатна, малонова, фумарова та яблучна

3. Найбільший вміст органічних кислот було визначено в листі, заготовленому у фазу вегетації.

4. Одержані результати дають змогу прогнозувати антиоксидантну та протимікробну активність лікарських рослинних засобів на основі сировини амброзії полинолистої.

\section{СПИСОК ЛІТЕРАТУРИ}

1. Коновалова О. Ю. Дослідження органічних кислот у деяких рослинах родини Elegnaceae / О. Ю. Коновалова, Є. М. Гергель, О.П.Колядич // Запорож. мед. журн. - 2012. - № 4 (73). - С. 107-108.

2. Марчишин С. М. Органічні кислоти надземної частини видів роду Ocimum L. / C. М. Марчишин, М. І. Шанайда, А. І. Дуб // Pharmaceutical review. 2014. - № 4. - С. 13-16.

3. Тринеева О. В. Определение органических кислот в листьях крапивы двудомной / О.В. Тринеева,
А. И. Сливкин, С. С. Воропаева // Вестн. ВГУ. Серия “Химия. Биология. Фармация". - 2013. - № 2. C. 215-219.

4. Грицик Л. М. Ідентифрікація та кількісне визначення органічних кислот у траві видів приворотня / Л. М. Грицик, Н. І. Тучак, А. Р. Грицик // Фармац. журн. 2013. - № 3. - С. 83-87.

5. Определение аскорбиновой кислоты и органических кислот в желудочных сборах различных производителей Украины / В. С. Кисличенко, А. И. Федо- 
сов, А. А. Кисличенко, Е. Н. Новосел // Фармац. журн. - 2015. - № 2. - С. 12-15.

6. Role of fumaric acid in anti-inflammatory and analgesic activities of a Fumaria indica extracts / A. Shakya, G. K. Singh, S. S. Chatterjee, V. Kumar // Journal of Intercultural Ethnopharmacology. - 2014. - 3, No. 4. P. 173-178.

\section{REFERENCES}

1. Konovalova, O.Yu., Herhel, Ye.M., Koliadych, O.P. (2012). Doslidzhennia orhanichnykh kyslot u deiakykh roslynakh rodyny Elegnaceae. Zaporozhskiy meditsynskiy zhurnal - Zaporizhzhia Medical Journal, 4 (73), 107-108 [in Ukrainian].

2. Marchyshyn, S.M., Shanaida, M.I., \& Dub, A.I. (2014). Orhanichni kysloty nadzemnoi chastyny vydiv rodu Ocimum L. Pharmaceutical Review, 4, 13-16 [in Ukrainian].

3. Trineeva, O.V., Slivkin, A.I., \& Voropaeva, S.S. (2013). Opredelenie organicheskikh kislot v listyakh krapivy dvudomnoy [Determination of organic acids in the leaves of the nettle dioecious]. Vestnyk VGU, seriya: Khimiya. Biologiya. Farmatsiya, 2, 215-219 [in Russian].

4. Hrytsyk, L.M., Tuchak, N.I., \& Hrytsyk, A.R. (2013). Identyfikatsiia ta kilkisne vyznachennia orhanichnykh kyslot u travi vydiv pryvorotnia [Identification and quantitative determination of organic acids in the grass are of a kind of alchemilla]. Farmatsevtychnyi zhurnal - Pharmaceutical Journal, 3, 83-87 [in Ukrainian].

5. Kislichenko, V.S., Fedosov, A.I., Kislichenko, A.A., Novosel, E.N. (2015). Opredelenie askorbinovoy kisloty
7. A review of plants used in ethnoveterinary medicine / V. Davidovic, M. Joksimovic-Todorovic, Z. Maksimovic [et al.] // Maced. J. Anim. Sci. - 2011. - 1 (2). - P. 377-382.

8. Горяча Л. М. Дослідження вмісту карбонових кислот у густому екстракті трави амброзії полинолистої / Л. М. Горяча, І. О. Журавель // Зб. наук. праць співробітників НМАПО ім. П. Л. Шупика. - 2015. Вип. 24, кн. 5. - С. 82-87.

i organicheskikh kislot $v$ zheludochnykh sborakh razlichnykh proizvoditeley Ukrainy [Determination of ascorbic acid and organic acids in gastric collections of various Ukrainian producers]. Farmatsevticheskiy zhurnal Pharmaceutic Journal, 2, 12-15 [in Russian].

6. Shakya, A., Singh, G.K., Chatterjee, S.S., \& Kumar, V. (2014). Role of fumaric acid in anti-inflammatory and analgesic activities of a Fumaria indica extracts. Journal of Intercultural Ethnopharmacology, 3 (4), 173-178.

7. Davidovic, V., Joksimovic-Todorovic, M., \& Maksimovic, Z. (2011). A review of plants used in ethnoveterinary medicine. Maced. J. Anim. Sci., 1 (2), 377382.

8. Horiacha, L.M., \& Zhuravel, I.O. (2015). Doslidzhennia vmistu karbonovykh kyslot u hustomu ekstrakti travy ambrozii polynolystoi [Investigation of the content of carboxylic acids in the thick extract of grass polystyrene embryos]. Zbirnyk naukovykh prats spivrobitnykiv NMAPO im. P.L. Shupyka - Collection of Scientific Works of Workers of NMAPGE by P.L. Shupyk, 24 (5), 82-87 [in Ukrainian].

\section{А. И. Панасенко ${ }^{1}$, Л. Н. Горячая ${ }^{2}$, В. В. Гуцол ${ }^{3}$ ЗАПОРОЖСКИЙ ГОСУДАРСТВЕННЫЙ МЕДИЦИНСКИЙ УНИВЕРСИТЕТ ${ }^{1}$

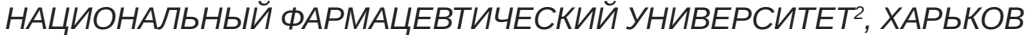 ВИННИЦКИЙ НАЦИОНАЛЬНЫЙ МЕДИЦИНСКИЙ УНИВЕРСИТЕТ ИМЕНИ Н. И. ПИРОГОВАЗ}

\section{ИССЛЕДОВАНИЕ ОРГАНИЧЕСКИХ КИСЛОТ В СЫРЬЕ АМБРОЗИИ ПОЛЫННОЛИСТНОЙ}

\section{Резюме}

Вступление. Перспективной группой биологически активных веществ растительного происхождения являются органические кислоты. Органические кислоты проявляют противовоспалительную, антиоксидантную, гепатозащитную, противомикробную активность, также они участвуют в обмене веществ и улучшают состояние микрофрлоры кишечника. В литературе достаточно ограничены сведения относительно органических кислот амброзии полыннолистной, поэтому исследование этой группы биологически активных веществ в сырье амброзии было актуальным.

цель исследования - изучить органические кислоты в сырье амброзии полыннолистной в разные фразы развития растения.

Методы исследования. Исследование органических кислот проводили методом газовой хроматографрии в листьях и корнях амброзии полыннолистной, заготовленных в фразе вегетации, в начале бутонизации и в фразе плодоношения. 
Результаты и обсуждение. В листьях амброзии полыннолистной, заготовленных в фразе вегетации, в наибольшем количестве содержались лимонная (4769,3 мг/кг) и оксалатная (2046,8 мг/к2) кислоты, в корнях этой фразы - фрумаровая (2580,9 мг/кг) и лимонная (782,3 мг/ка). В листьях, заготовленных в начале бутонизации, по содержанию превалировали оксалатная (1374,4 мг/к2) и лимонная (813,0 мг/к2) кислоты, в корнях этой фразы - лимонная (1705,1 мг/кг) и яблочная (1399,5 мг/к2). В листьях, заготовленных в фразе плодоношения, доминировали лимонная (2879,4 мг/кг) и оксалатная (513,5 мг/кг) кислоты, в корнях этой фразы по содержанию преобладали фрумаровая (242,2 мг/кг) и яблочная (186,7 мг/к2) органические кислоты.

Выводы. Методом газовой хроматографии были исследованы органические кислоты в листьях и корнях амброзии полыннолистной, которые были заготовлены в фразе вегетации, в начале бутонизации и в фразе плодоношения. В исследуемом сырье по содержанию преобладали алифратические карбоновые кислоты, в частности лимонная, оксалатная, малоновая, фумаровая и яблочная. Начбольшее содержание органических кислот было определено в листьях, заготовленных в фразе вегетации. Полученные результаты дают возможность спрогнозировать антиоксидантную и противомикробную активность лекарственных растительных средств на основе сырья амброзии полыннолистной.

КЛЮЧЕВЫЕ СЛОВА: амброзия полыннолистная; органические кислоты; газовая хроматография.

O. I. Panasenko ${ }^{1}$, L. M. Goriacha ${ }^{2}$, V. V. Hutsol $^{3}$ ZAPORIZHZHIA STATE MEDICAL UNIVERSITY ${ }^{1}$ NATIONAL UNIVERSITY OF PHARMACY², KHARKIV M. PYROHOV VINNYTSIA NATIONAL MEDICAL UNIVERSITY ${ }^{3}$

\section{THE ORGANIC ACIDS STUDY IN COMMON RAGWEED PLANT MATERIAL}

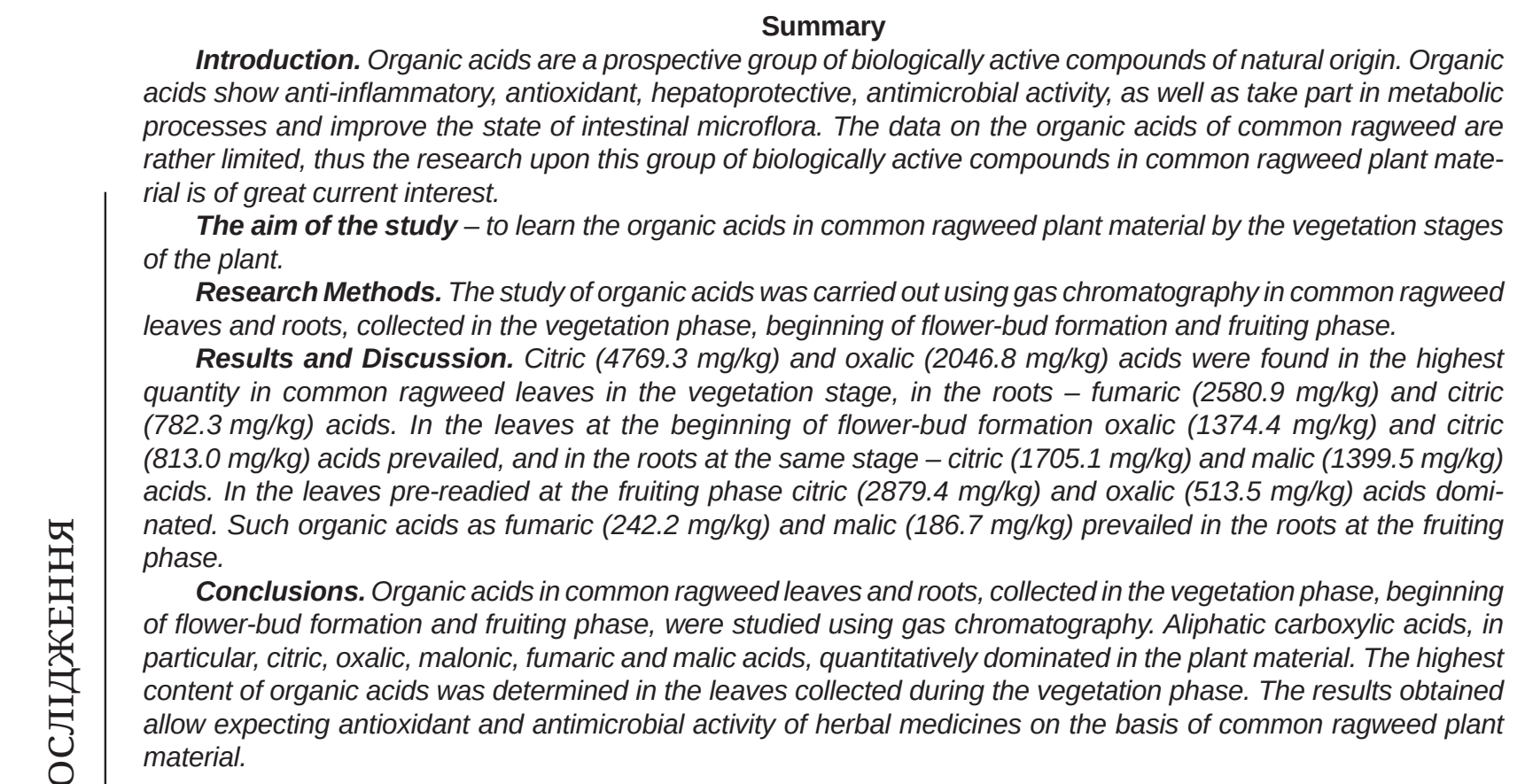

KEY WORDS: common ragweed; organic acids; gas chromatography.

Адреса для листування: Л. М. Горяча, Національний фрармацевтичний університет, вул. Пушкінська, 53, Харків, 61002, Україна, e-mail: lilia4252@ukr.net. 